\title{
The quality of geothermal reservoir of the Lower Jurassic aquifer in the Mogilno-Łódź Trough (Polish Lowlands)
}

\author{
Aleksandra Kasztelewicz ${ }^{1, *}$ and Barbara Tomaszewska² \\ ${ }^{1}$ MEERI PAS, J. Wybickiego 7A, 31-261 Kraków, Poland \\ ${ }^{2}$ AGH University of Science and Technology, A. Mickiewicza 30, 30-059 Kraków, Poland
}

\begin{abstract}
The assessment of the geothermal potential should always take an accurate identification of the geological conditions into account. Petrographic and petrophysical investigations of the aquifers allow to estimate their productivity and infectivity. The area of the Mogilno-Łódź Trough is next to the Podhale basin, one of the most prospective regions in terms of geothermal potential in Poland. The Lower Jurassic aquifers are characterized by the largest dispositional resources among geothermal aquifers in the Polish Lowlands. The Lower Jurassic geothermal reservoir consist of fine and mixed grain-size sands and sandstones layers from 10$650 \mathrm{~m}$ thick, depending on the depth. The water within the reservoir exhibits mineralization ranging from 2 to over $250 \mathrm{~g} / \mathrm{L}$ and its temperature ranges from 30 to $100^{\circ} \mathrm{C}$. Boreholes profiles selected for study consist Lower Jurassic formations of the Polish Lowlands, which are perspective for the heat production in Poland. Sandstones are represent mainly by quartz arenites and subordinate by quartz wackes. Parameters measured include among others porosity, permeability and surface area. The results of the petrographic and mineralogical studies of core samples confirmed the presence of rock with favorable parameters for geothermal water accumulation.
\end{abstract}

Keywords: geothermal resources, Polish Lowlands, aquifer characteristic, reservoir rocks

\section{Introduction}

The basic condition for the accumulation of groundwater is the occurence of reservoir rocks with favorable parameters. The success of geothermal water exploration depends in large part of finding reservoirs with sufficient porosity and permeability to support commercial development. Assessing the quality of geothermal reservoir plays an important role in the mitigation of the risk of not finding suitable resources [1-3].

Mineral dissolution and precipitation reactions in porous media can result in changes in porosity and permeability $[4,5]$. Moreover, the lithology of reservoir rocks, as well as the water-rock thermodynamic equilibrium, affect the chemical composition of groundwater and

\footnotetext{
*Corresponding author: kasztelewicz@meeri.pl
} 
its exploitation [6]. The physicochemical properties of geothermal waters have a significant impact on the occurrence of clogging processes in geothermal systems. Corrosion and clogging of the water circulation system are one of the key problems associated with the exploitation of geothermal waters [7-11]. The impact of those reactions may affect in longterm operation of the geothermal systems [12].

Waters that filling the space rocks should be characterized by appreciating parameters, such as temperature, efficiency, and mineralization, indicating the possibility of their use for different purpose: heating, balneology, recreation, etc. The type of the rocks forming the Mesozoic formations of the Mogilno-Łódź Trough contribute to occur the fissured and porefractured water aquifers consisted mainly of sandstones, mudstones, and carbonate rocks.

The aim of this study was to widen the knowledge about the Lower Jurassic geothermal aquifer in the Mogilno-Łódź Trough. This is important issue, because it will allow a more precise identification of the aquifier parameters and therefore a more accurate design of the exploitation plant. Obtained parameters will be used for hydrogeochemical modelling to assess the quality of the reservoir and possible futher management of the resources.

\section{Geological background}

The area selected for detailed analyses covered the central part of Polish Lowlands - MogilnoŁódź Trough region (Fig. 1) where the largest potential for the use of geothermal waters of the Lower Jurassic reservoir occurs. The top of the Lower Jurassic formation lie over a depth of about 2,000 m b.g.l. up to 3,600 m b.g.l. in the axial part of the Through. Lower Jurassic aquifers consist of the sandstone complexes separated by a discontinuous series of poorly permeable and practically impermeable sediments, formed in the form of compact finegrained sandstones, siltstones and claystones. The thickness of these sandsotnes range from 10 to $650 \mathrm{~m}$ depending on the depth. Thinner sandstone complexes are associated with Hettangian, Synemurian, Uppoer Plienbachian and Upper Toarcian sediments. Lower Jurassic deposits lie on different Triassic members (Rhaetian sediments) and are covered with non-bearing Dogger deposits, sometimes Cretaceous, Tertiary, Neogene and Quaternary [13].

The water within the reservoir exhibits mineralization ranging from 2 to over $100 \mathrm{~g} / \mathrm{L}$ and its temperature ranges from 39 to $80^{\circ} \mathrm{C}$. The reservoir area is $158,600 \mathrm{~km}^{2}$, i.e. around $51 \%$ of the area of Poland [13-16]. Despite a high vertical variability, horizontal variation and numerous facies changes of the reservoir beds, it may be suggested that underground waters saturating the permeable Lower Jurassic strata from a continuous aquifer. Local discontinuities known from some structural units are caused mostly by fault-block tectonics [17-18].

Considering the possibility of accumulation of the geothermal energy in the Lower Jurassic formations, geological conditions analysis must be carried out in the presence of potential reservoir rocks. Geothermal aquifers can be evaluated from well data in terms of reservoir quality and reservoir production efficiency. In first case, it depends on estimates derived from a petrophysical analysis of existing well logs. The reservoir production efficiency is the product of reservoir quality, i.e. porosity and permeability, a continuity, i.e. stratigraphical complexity and production properties, i.e. temperature, salinity [19]. In the area of the Mogilno-Łódź Trough, the permeability coefficient ranges from several dozen $\mathrm{mD}$ to $1627.2 \mathrm{mD}$. Effective porosity of aquifers from the Lower Jurassic strata is within the limits of 7.95 to $25.35 \%$. The filtration coefficient ranges from $9.48 \times 10-8$ to $1.2 \times 10-5 \mathrm{~m} / \mathrm{s}$. The calculated potential capacity of boreholes in the analyzed area ranges from a few dozen

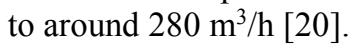




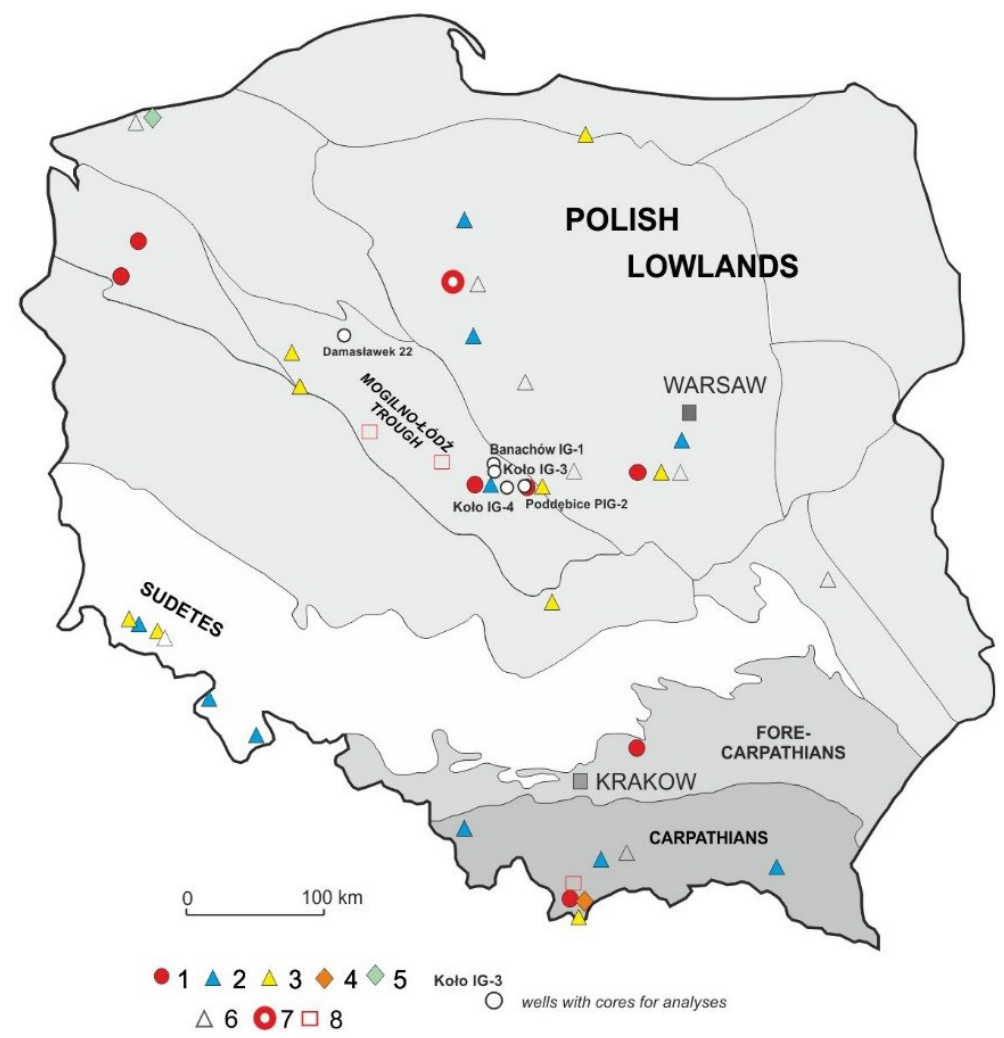

Fig. 1. Location of the examined boreholes and geothermal energy application in Poland, 2018 [21] 1 - district heating systems, 2 - health resorts, 3 - recreation centers, 4 - wood drying, 5 - fish farming, 6 - recreation centers in realization, 7 - heating system at early stage, 8 - some planned co-generation plants.

\section{Methods and samples}

In order to recognize parameters of rocks that form potential deep reservoirs, 12 samples of the Lower Jurassic rock formations were collected from the Mogilno-Łódź Trough from following borehole cores: Banachów IG-1, Damasławek 22, Koło IG-3, Koło IG-4, and Poddębice PIG-2.(Tab.1) Samples were taken from various depths between 2732.5 and $3633.5 \mathrm{~m}$ below surface where temperatures of geothermal waters exceed $80^{\circ} \mathrm{C}$. A small number of samples resulted from the limitations of the size of cores in the archives. Samples collected for detailed mineralogical and petrographic study cores had to meet the size requirements for microscopic examination.

The study included petrographic thin-section observation and petrophysical analyses of core cutting samples. Several sedimentological approaches were used: thin-section petrography, SEM analysis, XRD analysis as well as petrophysic analysis. Petrographic thin sections were examined in detail with an optical polarizing microscope Olimpus BX-51 to determine mineral composition, cement type, sedimentary features, and pore size distribution. Porosity measurements were carried out on a polarizing microscope with one nickel and 200X magnification. The measurements were carried out in a 40x40 square grid, which gave a total of 1,600 measuring points. Scanning electron microscope FEG Quanta 250 equipped with a chemical composition analysis system based on X-ray energy dispersion - EDDA by EDAX was used to interpret the cement types and diagenetic features. X-ray 
analysis (XRD) was performed using the powder method Philips X'pert APD X-ray diffractometer with a PW 3020 goniometer and $\mathrm{Cu}$ lamp and a graphite monochromator. Analyses were performed in the 5-65 $2 \theta$ angle range. Philips X'Pert software was used to process diffraction data. The identification of mineral phases was based on the PCPDFWIN database ver. 1.30 formalized by JCPDS - ICDD. Petrophysical analysis included density measurement, porosity measurement performed by mercury porosimetry and permeability coefficient measurement performed by applying gas method.

\section{Results and discussion}

Rocks collected from all the wells can be classified petrographically as sandstones represent mainly by quartz arenites. A skeleton size distribution of these sandstones is characterized by a well-sorted clastic material and monotonous mineral composition. In all samples, the framework is dominated by quartz grains whose content is between $97 \%$ for samples from profiles from the Koło, Damasławek and Poddębice, up to $99 \%$ for samples from Banachów. All analysed samples contain quartz lithoclasts up to $1 \%$ in all samples except for the Banachów profile where their quantity does not exceed $0.1 \%$. The subordinate components are represented also by: light micas (up to $1 \%$ in Banachów, Koło, Poddebice) and heavy minerals (up to $1 \%$ Koło, Damasławek).

Size of quartz grains are varied, from 0.05 to $0.6 \mathrm{~mm}$, most of the grains are characterized by the presence of regenerative edging, as well as the dissolution traces pressure. Quartz grains often show a wavy type of light extinction (Fig. 2a). Feldspars, represented by plagioclase and perthite up to $0.2 \mathrm{~mm}$, occur sporadically in samples and mostly are completely changed as a result of seretisations or replaced by iron-clayey substance similar to the matrix one. Micas, represented by 0.2 to $0.3 \mathrm{~mm}$ long muscovite and chlorites sheets, are commonly in framework of all examined sandstones, as well as heavy minerals (zircon, tourmaline, and apatite). Increased content of heavy minerals in sample form the borehole Koło IG-4 (2732.5 m b.g.l.) was observed (Fig. 2a).

The cement in the studies rocks consists mainly of regenerative quartz from $60 \%$ in Koło and Banachów profile, up to $90 \%$ in samples from Poddębice (tab. 1). Subordinate occurs kaolinite porous binder (up to $18 \%$ in Koło IG-4 profile). Porous carbonate cement (Fig. 2b) and iron-clayed matrix occur in small amounts mainly in profile from Banachów and Damasławek (Fig. 2c). Additionaly in sample from the Damasławek 22: $3391.3 \mathrm{~m}$ b.g.l. (Fig. 2d) the anhydrite cement was observed. The quartz cement forms a syntaxial boundary on quartz grains that grows over the sandstone pore spaces occur also in Poddębice PIG-2 well [22].

A scanning electron microscopy confirmed the presence of a primary regeneration quartz binders (Fig. 3a) with a kaolinitic cement (Fig. 3b). Two generations of autogenous quartz were also observed in the Poddębice PIG-2 borehole profile [22]. Kaolinite is formed in hexagonal plates, as overlapping sheets (Fig. 3c). The presence of clay-ferruginous cement has been observed in the Damasławek profile (Fig. 3d). Besides, observations of the samples using micro-scanning microscopy showed the presence of halite efflorescence which forms shapeless toppings in the profile Poddębice (Fig. 3e) or regular crystals as in the sample from Banachów IG-1 (Fig. 3f). Observations in the polarization and scanning microscope have been confirmed by diffraction analysis. The sandstones studied are constructed exclusively from quartz accompanied by small amounts of kaolinite (Fig 4).

The results of automatic porosity analysis made on thin sections of the profile of Lower Jurassic rocks indicate a similar degree of porosity of all sandstones (Table 1). Most of the samples analyzed are characterized by a porosity of several up to dozen percent. The lowest and the highest porosity were indicated in samples from Poddębice PIG-2 at the depth of (3364.5 m b.g.1.) and (3623.0 $\mathrm{m}$ b.g.1.) respectively. 
Table 1. Results of petrographic analysis.

\begin{tabular}{|c|c|c|c|c|c|c|}
\hline $\begin{array}{l}\text { Sam } \\
\text { ple } \\
\text { No }\end{array}$ & $\begin{array}{l}\text { Localization } \\
\text { (well) }\end{array}$ & $\begin{array}{l}\text { Depth } \\
{[\mathrm{m}} \\
\text { b.g.l.] }\end{array}$ & $\begin{array}{l}\text { Mineralogical } \\
\text { composition* }\end{array}$ & Binder** & $\begin{array}{c}\text { Automat } \\
\text { ic } \\
\text { porosity } \\
{[\%]} \\
\end{array}$ & $\begin{array}{c}\text { Variation } \\
\text { coefficient } \\
{[\%]}\end{array}$ \\
\hline 1 & $\begin{array}{l}\text { Banachów } \\
\text { IG-1 }\end{array}$ & 3344.5 & $\begin{array}{c}\mathrm{Q}-99 \% \\
\mathrm{~L}-1 \%\end{array}$ & $\begin{array}{c}\mathrm{P}_{\text {kaolinitic }}-55 \% \\
\mathrm{P}_{\text {carbonate }}-30 \% \\
\mathrm{R}_{\mathrm{Q}}-10 \% \\
\mathrm{P}_{\text {ferruginous }}-5 \%\end{array}$ & 11.29 & 50.5 \\
\hline 2 & $\begin{array}{l}\text { Banachów } \\
\text { IG-1 }\end{array}$ & 3380.7 & $\begin{array}{c}\mathrm{Q}-99 \% \\
\mathrm{~L}-1 \%\end{array}$ & $\begin{array}{c}\mathrm{R}_{\mathrm{Q}}-60 \% \\
\mathrm{P}-40 \%\end{array}$ & 9.15 & 43.4 \\
\hline 3 & Koło IG-3 & 3079.4 & $\begin{array}{c}\mathrm{Q}-97 \% \\
\mathrm{~L}-1 \% \\
\mathrm{M}-1 \% \\
\mathrm{H}-1 \% \\
\end{array}$ & $\begin{array}{c}\mathrm{R}_{\mathrm{Q}}-90 \% \\
\mathrm{CP}_{\text {kaolinitic }}-10 \%\end{array}$ & 10.81 & 36.2 \\
\hline 5 & Koło IG-4 & 2732.5 & $\begin{array}{c}\mathrm{Q}-98 \% \\
\mathrm{~L}-1 \% \\
\mathrm{H}-1 \% \\
\end{array}$ & $\begin{array}{c}\mathrm{R}_{\mathrm{Q}}-80 \% \\
\mathrm{P}_{\text {kaolinitic }}-18 \% \\
\mathrm{P}_{\text {carbonate }}-2 \% \\
\end{array}$ & 11.21 & 27.3 \\
\hline 6 & Koło IG-4 & 2766.5 & $\begin{array}{c}\mathrm{Q}-99.5 \% \\
\mathrm{~L}-0.5 \%\end{array}$ & $\begin{array}{c}\mathrm{R}_{\mathrm{Q}}-60 \% \\
\mathrm{P}_{\text {ferruginous-carbonate }}- \\
25 \% \\
\mathrm{P}_{\text {sparite }}-10 \% \\
\mathrm{P}_{\text {kaolinitic }}-5 \%\end{array}$ & 12.61 & 25.1 \\
\hline 7 & $\begin{array}{l}\text { Poddębice } \\
\text { PIG-2 }\end{array}$ & 3364.5 & $\begin{array}{c}Q-97 \% \\
L-1 \% \\
M-1 \% \\
H-1 \%\end{array}$ & $\begin{array}{c}\mathrm{R}_{\mathrm{Q}}-90 \% \\
\mathrm{P}_{\text {kaolinitic/ clay-ferruginous }} \\
-10 \%\end{array}$ & 7.03 & 49.6 \\
\hline 9 & $\begin{array}{l}\text { Poddębice } \\
\text { PIG-2 }\end{array}$ & 3623.0 & $\begin{array}{c}\mathrm{Q}-99 \% \\
\mathrm{~L} / \mathrm{M} / \mathrm{H}-1 \% \\
\end{array}$ & $\begin{array}{c}\mathrm{R}_{\mathrm{Q}}-85 \% \\
\mathrm{P}_{\text {kaolinitic }}-15 \% \\
\end{array}$ & 13.99 & 20.2 \\
\hline 10 & $\begin{array}{l}\text { Damasławe } \\
\text { k } 22\end{array}$ & 3391.3 & $\begin{array}{c}\mathrm{Q}-99 \% \\
\mathrm{Ch} / \mathrm{F}-1 \%\end{array}$ & $\begin{array}{c}\mathrm{CP}_{\mathrm{Q}}-75 \% \\
\mathrm{C}_{\text {carbonate/anhydrite }}- \\
25 \% \\
\end{array}$ & 10.29 & 35.0 \\
\hline 11 & $\begin{array}{c}\text { Damasławe } \\
\text { k } 22\end{array}$ & 3584.3 & $\begin{array}{l}\mathrm{Q}-95 \% \\
\mathrm{~L}-4 \% \\
\mathrm{~F}-1 \%\end{array}$ & $\mathrm{P}_{\text {clay-ferruginous }}$ & 12.91 & 35.1 \\
\hline 12 & $\begin{array}{l}\text { Damasławe } \\
\text { k } 22\end{array}$ & 3633.5 & $\begin{array}{c}\mathrm{Q}-98 \% \\
\mathrm{M}-0.5 \% \\
\mathrm{~L}-0.5 \%\end{array}$ & Clay iron matrix & 11.99 & 42.6 \\
\hline
\end{tabular}

*Q $\mathrm{Q}$ - quartz, $\mathrm{L}$ - lithoclasts, $\mathrm{M}$ - micas, $\mathrm{H}$ - heavy minerals, $\mathrm{Ch}$ - chlorite, $\mathrm{F}$ - feldspares

$* * \mathrm{R}-$ regenerative, $\mathrm{P}$ - porous, $\mathrm{CP}-$ contact porous, $\mathrm{C}-$ cement 

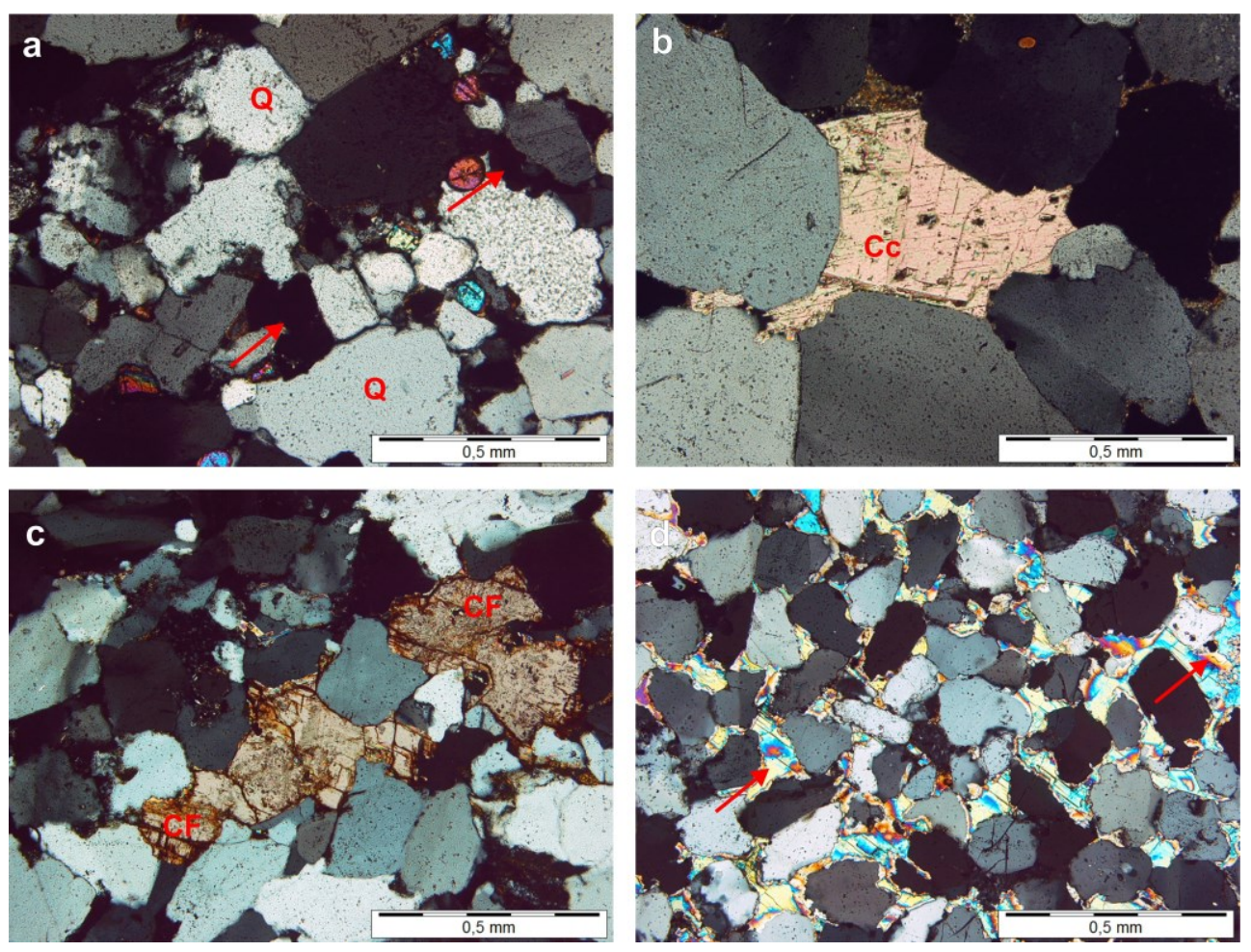

Fig. 2. Transmitted light microscopic images of Lower Jurassic rock samples, crossed polarizers: a - quartz grains (Q) with an undulate extinction pattern and an accumulation of heavy minerals (red arrows) (Koło IG-4: 2732.5 m b.g.1.); b - autogenic carbonate cement (Cc) (Koło IG-4: $2766.5 \mathrm{~m}$ b.g.1.); $\mathrm{c}$ - autogenic carbonate-ferruginous-clay cement (CF) (Banachów IG-1: $3380.7 \mathrm{~m}$ b.g.1.); d - anhydrite cement (red arrows) (Damasławek 22: $3391.3 \mathrm{~m}$ b.g.1.).

In general, the porosity of the studied sandstones were $11-12 \%$. From the petrophysical examination, the total porosity of the studied samples ranges from 7.88 to $14.83 \%$, effective porosity from 6.75 to $13.38 \%$. The specific surface area varies from 0.01 to $1.82 \mathrm{~m}^{2} / \mathrm{g}$. The size of this surface informs about the development of the pore space in the directions of micropores. The larger the surface is, the more micropores in the rock. The size of the surface area equal to zero indicates the lack of pore space, i.e. virtually no porosity.

The permeability perpendicular to the core axis is from 0.151 to $129.023 \mathrm{mD}$. The permeability parallel to the core axis is from $0.141-95.58 \mathrm{mD}$. In the sample from the Damasławek-22 well (3391.3 m b.g.l.), the permeability parallel to the core is 5 times greater than the permeability perpendicular to the core axis.

Rock composition has a significant effect on the reservoir parameters such as porosity and permeability. High porosity and permeability play a significant role in fluid migration $[4,6]$. Sandsotnes from boreholes located in the Mogilno-Łódź Trough represents mainly by quartz arenites and wackes which have variation in porosity and permeability ( $\min .7 .03 \%$, $\mathrm{m}$ max. $13.99 \%$ ). Anomalously low permeability in relation to the pore space parameters is shown in the Koło IG-4 sample (2732.4 m b.g.l.). Lowering the permeability in relation to the pore space parameters is related to the partial cementation of the rock [22]. Cement in the rock are nested and the sample has very low permeability despite very good parameters of the pore space. Cements are represents mainly by quartz, clay minerals, carbonates and locally ferrous minerals. The quartz regenerative cement is of higest importance in examined samples. The authigenic clay minerals are represented mainly by kaolinite. The carbonate cements include siderite. 

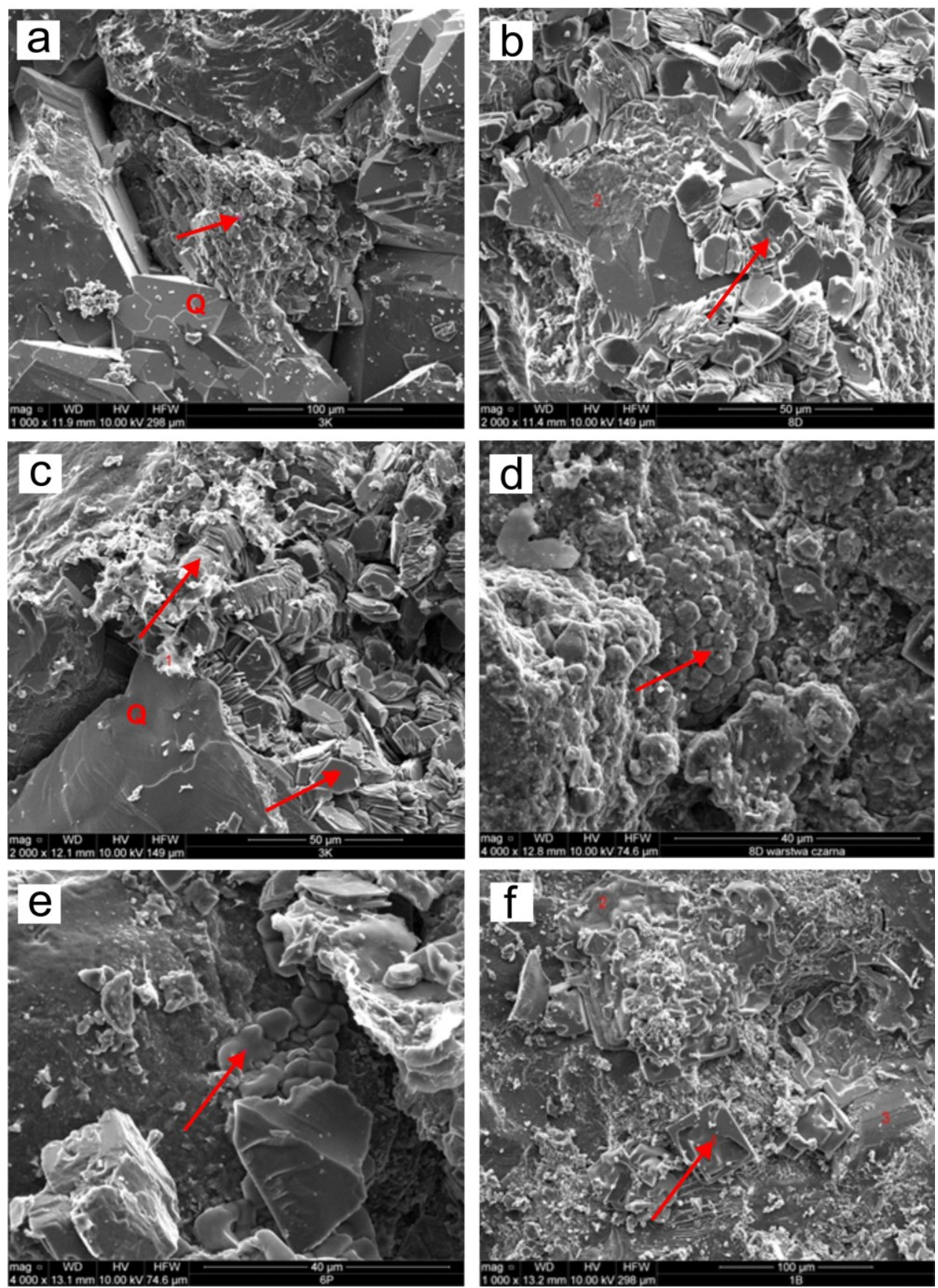

Fig. 3. Microstructures of sandstones samples found in the Lower Jurassic boreholes cores: a regenerative quartz cement (Koło IG-4: $2732.5 \mathrm{~m}$ b.g.1.); b - kaolinite cement (Damasławek 22: 3391.3 m b.g.l.); c - kaolinite cement (Koło IG-3: 3079.4 m b.g.l.); d - ferruginous-clay cement (Damasławk 22: $3391.3 \mathrm{~m}$ b.g.1.); $\mathrm{e}$ - halite efflorescences in the form of amorphous encrustations (Poddębice PIG2: $3364.5 \mathrm{~m}$ b.g.l.); $\mathrm{f}$ - halite efflorescences in the form of crystals with a regular habit (Banachów IG1: 3344.5 m b.g.l.). 


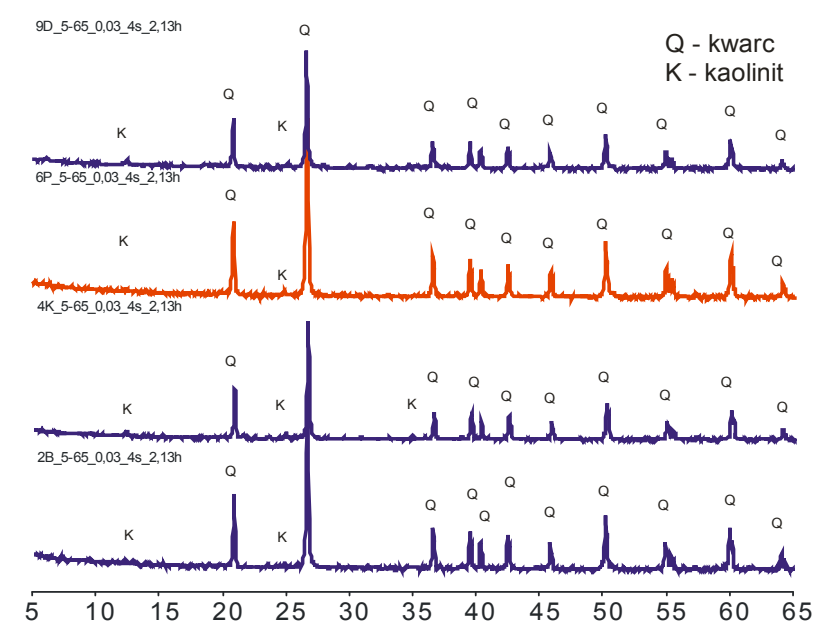

Fig. 4. Difractograms of the mineral composition of sandstones from Lower Jurassic profile.

The quality of the sandstone reservoirs depends on the depositional environment which affects among others sorting, grain size, matrix or diagenesis and as a result, they affect pore characteristics of the rock $[23,24]$. The main component of the fabric is quartz, lithiclast, micas, heavy minerals and feldspares are in a minority. Primary pores and pore connectivity is affected by grain size, smaller grains having more effect than coarse grains. The spaces between the detritic grains are filled with cement and iron-clay matrix which affect on the primary porosity.

In the studied sandstones the effects of diagenetic processes that shape the pore space are visible: compaction, cementation and dissolution. Quartz due to tectonic movements or as a result of compaction - has undergone dynamic deformations resulting in observed wavy light quenching on many grains. Cementation is a process that could significantly reduce the porosity of sandstones.

Carbonate cements filling the free pore spaces reduced its porosity as well as kaolinite cement occurring in the inter-grain pore. Dissolution processes are visible mostly on feldspar grains and lithoclasts. Additionaly, feldspar dissolution plays an important role for the generatin of quartz cement as well as ilitization of smectite at a deeper depth with high temperature [22]. Dissolution of rock fragments and feldspars are evidence of secondary porosity that enhance the reservoir quality.

\section{Conclusions}

Petrographic characteristic of the Lower Jurassic core samples was evaluated with help of core macroscopic observation and thin-section studies. Following methods have been applied: polarization microscope, scanning electron microscope, deffractometry and petrophysical studies. The study sandstones represents mainly by quartz arenites and wackes from medium- to finegrained. Study have confirmed that the Lower Jurassic sandstones from the Mogilno-Łódź trough, at the deepths between 2732.5 and $3633.5 \mathrm{~m}$ below surface are characterised minly by low and good porosity (7-14\%). The permeability varies from 0.151 to $129.023 \mathrm{mD}$. The results showed that the Lower Jurassic reservoir is perspecitive for geothermal water accumulation.

Reservoir consists of primary intergranular pores as well as dissolve secondary pores that enhance the reservoir characteristics. The reservoir quality was affected by the diagenetic process includes compaction, presence authigenic clay minerals, quartz overgrowth, and carbonate cement, as well as feldspar and lithoclasts dissolution. Compaction, clay minerals, 
calcite cement, and quartz overgrowth cause porosity loss and rock densification, whereas reservoir quality is enhanced by the dissolution of carbonate cement, leaching of feldspar and rock fragment.

Geothermal energy is recognized as one of the key sources for Poland's energy needs in the coming years. That is why it is important to recognise a geological reservoir with geothermal potential. Petrographic and petriphysic analyses represent one of many ways to assess the reservoir quality and understanding the potential impact of mineral reaction on formations properties. Presented studies will provide data on some relevelant paramters which affect on geothermal exploration and are used in the hydrogeological modelling.

The presented research was carried out under the Project ordered by the Ministry of Environment and financed by the National Found for Environmental and Water Management [no 398/2011/Wn-06/FGhg-tx/D].

\section{References}

1. A. Kasztelewicz, Insurance for geothermal projects, European countrie's good practices. Geological Exploration Technology, 1/2016, 173-183 (2016) (in Polish)

2. B. Tomaszewska, A. Kasztelewicz, M. Dendys, W. Bujakowski, S. Rahner, M. Hartmann, J. Weinreich, E3S Web Conf, 66, 03005 (2018) doi: $10.1051 /$ e3sconf/20186603005

3. S. Rahner, I. Winter, M. Hartmann, F. Wittig, A. Kasztelewicz, B. Tomaszewska, L. Pająk, M. Dendys, A. Operacz, M. Mraz, S. Nistor, E3S Web Conf, 66, 03004 (2018) doi: 10.1051/e3sconf/20186603004

4. J. Steinwiner, L.E. Beckingham, Water Resour Res, 55 (2019) doi: 10.1029/2019WR024793

5. T.R. Tylor, M.R. Giles, L.A. Hathon, T.N. Diggs, N.R. Braunsdorf, G.V. Birbiglia, I.S. Espejo, AAPG Bulletin, 94, 1093-1132 (2010) doi: 10.1306/04211009123

6. L. André, V. Rabemanana, F.D. Vuataz, Influence of water-rock interactions on fracture permeability of the deep reservoir at Soultz-sous-Forêts, France, Geothermics 35, 507 531 (2006)

7. B. Tomaszewska, L. Pająk, B. Bielec, The prognosis of clogging processess in injection wells during pumping colled thermal waters. Biul. PIG, 456, 615-620, (2013)

8. M. Rajca, B. Tomaszewska, E. Kmiecik, M. Bodzek, W. Bujakowski, K. Wątor, M. Tysze, Desalin Water Treat 73, 198-207 (2017), doi: 10.5004/dwt.2017.20358

9. B. Tomaszewska, E. Kmiecik, K. Wątor, M. Tyszer, Desalination, 427, 27-34 (2017) doi: 10.1016/j.desal.2017.11.004

10. B. Tomaszewska, M. Tyszer, Desalination, 424, 102-109 (2018) doi: 10.1016/j.desal.2017.10.003

11. M. Brehme, K. Nowak, D. Banks, S. Petrauskas, R. Valickas, K. Bauer, N. Burnside, A. Boyce, Gofluids, doi: 10.1155/2019/4363592

12. P. Ungemach, A.M. Papachristou, Proceedings World Geothermal Congress, (2005)

13. W. Górecki (ed.), Atlas of geothermal resources of Mesozoic formations in the Polish Lowlands. In: Ministry of Environment. Ed. ZSE AGH, Kraków, p. 484 (2006)

14. W. Górecki, M. Hajto, W. Strzetelski, A. Szczepański (2010) Lower Creataceous and Lower Jurassic aquifers in the Polish Lowlands. Przegląd Geologiczny 58, 589-593 (2010) (in Polish). 
15. A. Sowiżdżał, Renew Sust Energ Rev 82, 4020-4027 (2017) doi: 10.1016/j.rser.2017.10.070

16. T. Maćkowski, A. Sowiżdżał, A. Wachowicz-Pyzik, Geofluids vol 2019, Article ID 3052806, doi: 10.1155/2019/3052806 (2019)

17. W. Górecki, A. Sowiżdżał, M. Hajto, A. Wachowicz-Pyzik, Environ Earth Sci 74, 74877495 (2015) doi: 10.1007/s12665-014-3832-2

18. A. Szczepańki A (1990) Hydrogeothermal conditions of the Lower Jurassic and Lower Cretaceous geothermal reservoir - Lower Cretaceous reservoir. In: W. Górecki (ed) Atlas of geothermal resources of Mesozoic formations in the Polish Lowlands, Wyd. ZSE AGH, Kraków, 103-116 (1990) (in Polish)

19. A. Mathiesen, L. Kristensen, MC. Nielsen, R. Weibel, ML. Hjuler, B. Røgen, A. Mahler, $\mathrm{H}$. Nielsen, Assessment of sedimentary geothermal aquifer parameters in Denmark with focus on transmissivity. In: Proceedings European Geothermal Congress 2013. Paper No HS1-41 (2013)

20. A. Sowiżdżał, The geothermal potential of Mesozoic aquifers in the Polish Lowlands for the production of the electricity. Geological Exploration Technology. Geothermics. Sustainable Development, 2/2016, 105-115 (2016) (in Polish).

21. B. Kępińska, A review of geothermal energy uses in Poland in 2016-2018. Geological Exploration Technology. Geothermics. Sustainable Development, 1/2018, 11-27 (2018) (in Polish).

22. A. Kozłowska, A. Krystkiewicz, Results of petrographic research of the Lower Jurassic sediments. In: K. Leszczyński (ed) Profile głębokie otworów wiertniczych - Poddębice PIG-2, 133 (2012) (in Polish).

23. L. Caracciolo, J. Arribas, R.V. Ingersoll, S. Critelli S, The diagenetic destruction of porosity in plutoniclastic petrofacies: The Miocene Diligencia and Eocene Maniobra formations, Orocopia Mountains, southern California, USA. In : Scott R. A., Smyth H. R., Morton, A. C. \& Richardson N. (eds) Sediment Provenance Studies in Hydrocarbon Exploration and Production. Geological Society, London, Special Publication 386. London UK. (2013).

24. C. Ross, O. Kälin, J. Arribas, A. Tortosa, Mar Pet Geol 19, 117-142, (2002) doi: 10.1306/2DC40955-0E47-11D7-8643000102C1865D. 